\title{
Influence of L-Sorbose on Growth and Enzyme Synthesis of Trichoderma reesei C-5
}

\author{
By D. K. SAHOO, SAROJ MISHRA* AND V. S. BISARIA \\ Biochemical Engineering Research Centre, Indian Institute of Technology, Delhi, Hauz Khas, \\ New Delhi 110016, India
}

(Received 30 October 1985; revised 12 April 1986)

\begin{abstract}
The effects of L-sorbose on the growth and biosynthesis of cellulases and other polysaccharidedegrading enzymes of Trichoderma reesei $\mathrm{C}-5$ were studied. The specific growth rate and yield of this strain in batch culture were reduced by $23 \%$ and $46 \%$ respectively on addition of $1 \%(\mathrm{w} / \mathrm{v})$ sorbose to Vogel's medium containing $1 \%(\mathrm{w} / \mathrm{v})$ glucose. The specific consumption rate of both sorbose and glucose decreased in the presence of the other sugar at $1 \%(\mathrm{w} / \mathrm{v})$ concentration. The addition of sorbose $(1-5 \%)$ to cultures grown in $1 \%$ glucose resulted in enhanced activities of all cellulase enzymes, and particularly endoglucanase activity, which increased sevenfold in the presence of $5 \%$ sorbose. There was no significant effect on the activities of $\beta$-glucosidase, acid phosphatase and amylase. While the increased enzyme activities seemed to be correlated with a decreased rate of glucose consumption, a direct effect on some extracellular enzymes could not be ruled out.
\end{abstract}

\section{INTRODUCTION}

A high total surface to volume ratio and especially an increase in the number of growing hyphal tips are conducive to exoenzyme secretion in fungi (Stavy et al., 1970). L-Sorbose, a ketohexose, has been shown to cause an aberration of $1,3-\beta$-glucan synthesis in fungi, leading to distinct changes in morphology and growth pattern, a phenomenon known as 'paramorphogenesis', first described by Tatum et al. (1949) in Neurospora crassa. Bisaria et al. (1986) showed that the presence of sorbose in the growth medium of Trichoderma reesei QM9414 containing cellobiose resulted in the formation of tight mycelial pellets. A change in the composition of the cell wall, and increased branching and septation, were noticed. The uptake of cellobiose was also affected by sorbose. These factors have been shown to be involved in increased activities of extracellular cellulases in $T$. reesei QM9414.

The cellulases from $T$. reesei have been extensively studied for their potential applications in the hydrolysis of renewable lignocellulosic residues (Bisaria \& Ghose, 1981; Gilbert \& Tsao, 1983). The present work was undertaken to study the effect of sorbose on morphological changes in $T$. reesei C-5, a partially constitutive mutant derived from QM9414, and its relationship with the distribution of cellulase enzymes in various subcellular fractions of the fungus. The effects of sorbose on specific growth rate, yield and specific sugar consumption rate of the fungus were also studied for their possible involvement in increased enzyme synthesis.

\section{METHODS}

Organism and growth medium. Trichoderma reesei C-5, a partially constitutive cellulase-producing mutant derived from T. reesei QM9414 (Mishra et al., 1982), was used. The culture was maintained on Vogel's minimal medium (Vogel, 1956) supplemented with $0.1 \%(w / v)$ peptone and $1 \%(w / v)$ sucrose. It was stored at $4{ }^{\circ} \mathrm{C}$ and subcultured every four weeks.

† Abbreviation: FPA, Filter paper activity. 
The organism was grown in Vogel's minimal medium containing (w/v) $0 \cdot 1 \%$ peptone, $0 \cdot 2 \%$ Tween 80 and $1 \%$ glucose, $1 \%$ L-sorbose or $1 \%$ glucose plus $0.5-5.0 \% \mathrm{~L}$-sorbose as appropriate for each experiment.

Batch cultures. These were grown with shaking at $28^{\circ} \mathrm{C}$ in $500 \mathrm{ml}$ flasks containing $100 \mathrm{ml}$ medium. The cultures were inoculated and grown as described previously (Mishra \& Gopalkrishnan, 1984). Samples were removed every $4 \mathrm{~h}$ (for $1 \%$ glucose and $1 \%$ glucose plus $1 \%$ sorbose) or $6 \mathrm{~h}$ (for $1 \%$ sorbose) during the exponential growth phase, and centrifuged at $687.5 \mathrm{~g}$ for $20 \mathrm{~min}$. The supernatant was assayed for sugars, soluble protein and enzyme activities.

In experiments involving biomass estimation, cultures were grown (shaken) under identical conditions in $250 \mathrm{ml}$ flasks containing $50 \mathrm{ml}$ medium. The entire contents of the flasks were harvested at the end of every $6 \mathrm{~h}$ during the exponential growth phase and centrifuged. The mycelium was washed twice with distilled water, collected on Whatman no. 42 filter paper, and dried overnight at $85^{\circ} \mathrm{C}$ to a constant weight. The biomass yield $(Y)$ was calculated according to Trinci \& Collinge (1973) using the following equation:

$$
\begin{aligned}
Y & =\text { Maximum biomass (mg dry wt } \mathrm{ml}^{-1} \text { )/Sugar consumed (mg ml} \\
& =\Delta X / \Delta S
\end{aligned}
$$

When a mixture of glucose and sorbose was used the yield $(Y)$ was calculated as:

$$
Y=\Delta X /\left[(\Delta S)_{\text {glucose }}+(\Delta S)_{\text {sorbose }}\right]
$$

Estimation of sugars. Glucose was estimated in the growth medium by the Worthington Glucostat Reagent (Bergmeyer \& Brent, 1974) and sorbose by the cysteine. $\mathrm{HCl}$ method (Dische \& Devi, 1960).

The specific sugar consumption rate was defined as follows:

$$
\begin{aligned}
\text { Specific consumption rate } & =\frac{\text { Sugar consumed }\left(\mathrm{mg} \mathrm{ml}^{-1} \mathrm{~h}^{-1}\right)}{\text { Amount of biomass at time of assay }\left(\mathrm{mg} \text { dry wt } \mathrm{ml}^{-1}\right)} \\
& =(\mathrm{d} S / \mathrm{d} t) / X
\end{aligned}
$$

In the case of mixed sugars

$$
\text { Specific consumption of total sugar }=\left[(\mathrm{d} S / \mathrm{d} t)_{\text {glucose }}+(\mathrm{d} S / \mathrm{d} t)_{\text {sorbose }}\right] / X
$$

Subcellular fractionation. Cultures grown on different sugars $(2 \%$ glucose, $2 \%$ sorbose, $1 \%$ glucose $+1 \%$ sorbose) were withdrawn in duplicate at specific time intervals and centrifuged at $687.5 \mathrm{~g}$ for $20 \mathrm{~min}$. The supernatant was used to assay for extracellular enzymes. The mycelia were washed twice with distilled water and lyophilized.

A known quantity of lyophilized mycelia was suspended in a definite volume of $0.05 \mathrm{M}$-citrate buffer, $\mathrm{pH} 4.8$, and sonicated $(20 \mathrm{kHz})$ in an MSE sonicator $(20 \mathrm{ml}$ vessel, titanium probe, amplitude $6 \mu \mathrm{m})$ at $4{ }^{\circ} \mathrm{C}$ for $20 \mathrm{~min}$ with continuous cooling. The sonicated suspension was centrifuged at $11000 \mathrm{~g}$ at $4{ }^{\circ} \mathrm{C}$ for $30 \mathrm{~min}$. The supernatant was used as the source of intracellular enzymes while the residual pellet (washed three times with $0 \cdot 05 \mathrm{M}$-citrate buffer, $\mathrm{pH} 4.8$ ) suspended in a known volume of the same buffer, served as source of cell-wall-bound enzymes.

Enzyme assays. The samples were precipitated with acetone $(9 \mathrm{vols})$ at $4{ }^{\circ} \mathrm{C}$. The resulting precipitate was suspended in $0.05 \mathrm{M}$-citrate buffer, $\mathrm{pH} 4.8$, in a volume equal to the original sample volume. These preparations were used for determination of enzyme activities. The assays were done in triplicate; the values for replicate assays in all cases differed by less than $10 \%$ from the mean. All enzyme activities except amylase are reported as IU ml $\mathrm{ml}^{-1}$. One $\mathrm{IU} \mathrm{m} \mathrm{m}^{-1}$ represents the formation of $1 \mu \mathrm{mol}$ product $\mathrm{min}^{-1}(\mathrm{ml} \text { enzyme solution })^{-1}$ under the conditions of assay.

Filter paper activity (FPA) and endoglucanase activity were measured according to the method of Mandels $e$ al. (1976), with $50 \mathrm{mg}$ Whatman no. 1 paper $(6 \times 1 \mathrm{~cm})$ and $1 \%(\mathrm{w} / \mathrm{v})$ carboxymethylcellulose as substrate respectively. The reducing sugars released were measured by the dinitrosalicylic acid method (Sumner $\&$ Somers, 1949). $\beta$-Glucosidase was assayed according to Berghem \& Pettersson (1974), with $p$-nitrophenyl $\beta$-Dglucopyranoside as the substrate.

Amylase and acid phosphatase activities were measured according to Nisizawa et al. (1972), with $0 \cdot 2 \%$ amylose and $0.23 \mathrm{M}$-p-nitrophenyl phosphate as substrates. One amylase unit was defined as the amount of enzyme producing a $1.0 \%$ reduction of blue value.

Protein estimation. This was done by the Lowry method, with bovine serum albumin as the standard.

Chemicals. L-Sorbose was obtained from Fluka, and carboxymethylcellulose, cysteine hydrochloride, $p$ nitrophenyl $\beta$-D-glucopyranoside, $p$-nitrophenyl phosphate, amylose and bovine serum albumin from Sigma.

\section{RESULTS}

Growth and cellulase synthesis on glucose and sorbose. $T$. reesei strain C-5 was grown on $1 \%$ glucose, $1 \%$ sorbose and a mixture of $1 \%$ glucose and $1 \%$ sorbose, and growth, biomass yield and 
enzyme production were measured. The exponential phase of growth lasted for $24 \mathrm{~h}, 48 \mathrm{~h}$ and $28 \mathrm{~h}$ on the three respective media. Growth occurred in the form of tight pellets in the sorbosegrown cultures, compared to the long sparse mycelial growth in the cultures with glucose alone. The maximum biomass produced on $1 \%$ glucose was $6.0 \mathrm{mg} \mathrm{ml}^{-1}$, attained after $24 \mathrm{~h}$, while on $1 \%$ sorbose only $4.7 \mathrm{mg} \mathrm{ml}^{-1}$ accumulated after $52 \mathrm{~h}$ (Table 1 ).

The rate of consumption of the sugars differed. About $98 \%$ of the glucose was consumed in $24 \mathrm{~h}$ and the remainder after $30 \mathrm{~h}$. Sorbose was taken up relatively slowly: $20 \%$ was consumed in $24 \mathrm{~h}$ and the remaining $80 \%$ after $96 \mathrm{~h}$. The cultures grown on $1 \%$ sorbose gave more FPA (1.4 times), protein ( 1.1 times), endoglucanase ( 3.0 times) and $\beta$-glucosidase ( 1.5 times) on day 6 than the glucose-grown cultures (Table 1). The drop in the culture $\mathrm{pH}$ was greater $(\mathrm{pH}=3 \cdot 2)$ in glucose cultures than in sorbose cultures $(\mathrm{pH}=5 \cdot 0)$ (Table 1).

Table 1 also gives the values of maximum biomass, soluble protein and enzyme activities obtained on glucose plus sorbose. No significant increase in biomass was observed over the glucose-grown cultures, the maximum of $6.35 \mathrm{mg} \mathrm{ml}^{-1}$ being attained after $24 \mathrm{~h}$. The culture exhibited increased enzyme activity values for both the FPA and the endoglucanase components of cellulase. Specific endoglucanase activity was $2 \cdot 4$-fold higher than on glucose but slightly lower than in sorbose cultures.

Effect of sorbose on specific growth rate and yield. Addition of sorbose resulted in lowered specific growth rate of strain C-5 on $1 \%$ glucose : a sorbose concentration of $1 \%$ gave a decrease of $23 \%$, while $5 \%$ sorbose gave a decrease of $64 \%$ (Table 2 ). Similarly the yield of strain C-5 decreased by $46 \%$ and $62 \%$ when $1 \%$ and $5 \%$ sorbose respectively were added to $1 \%$ glucose medium (Table 2).

Specific consumption rate of sugar. Sorbose at a concentration of $1 \%$ decreased the specific consumption rate of glucose by $15 \%$ in a culture containing $1 \%$ glucose (Table 3 ). This effect was more pronounced (decrease of $71.5 \%$ ) when $5 \%$ sorbose was added to $1 \%$ glucose medium. The

Table 1. Synthesis of cellulase by $T$. reesei $C-5$ on glucose and sorbose medium after $6 d$

All parameters were measured on three independent cultures. Values for replicate assays in all cases differed by less than $7 \%$ from the mean.

\begin{tabular}{|c|c|c|c|c|c|c|}
\hline Carbon source & $\begin{array}{c}\text { Soluble } \\
\text { protein } \\
\left(\mathrm{mg} \mathrm{ml}^{-1}\right)\end{array}$ & $\begin{array}{c}\text { Maximum } \\
\text { biomass* } \\
\left(\mathrm{mg} \mathrm{ml}^{-1}\right)\end{array}$ & $\underset{\mathrm{pH} \dagger}{\operatorname{Minimum}}$ & $\begin{array}{c}\text { FPA } \\
\left(\mathrm{IU} \mathrm{ml^{-1 }}\right)\end{array}$ & $\begin{array}{l}\text { Endoglucanase } \ddagger \\
\quad\left(I \mathrm{U} \mathrm{ml} \mathrm{m}^{-1}\right)\end{array}$ & $\begin{array}{c}\beta- \\
\text { Glucosidase } \\
\left(\mathrm{IU} \mathrm{m \textrm {ml } ^ { - 1 }}\right)\end{array}$ \\
\hline Glucose $(1 \%)$ & 0.78 & $6.0 \quad(24 h)$ & $3 \cdot 2$ & $0.63(0 \cdot 8)$ & $4.8 \quad(6 \cdot 15)$ & $0.4 \quad(0.51)$ \\
\hline Sorbose $(1 \%)$ & $0 \cdot 88$ & $4.7 \quad(52 \mathrm{~h})$ & $5 \cdot 0$ & $0.85(0.96)$ & $14 \cdot 2(16 \cdot 13)$ & $0 \cdot 61(0.69)$ \\
\hline $\begin{array}{l}\text { Glucose }(1 \%) \\
+ \text { sorbose }(1 \%)\end{array}$ & $1 \cdot 38$ & $6 \cdot 35(24 h)$ & $3 \cdot 2$ & $1.3 \quad(0.94)$ & $20 \cdot 0(14.50)$ & $0.53(0.38)$ \\
\hline
\end{tabular}

* Maximum biomass attained after the time indicated in parenthesis.

$\dagger$ Minimum pH attained after $24 \mathrm{~h}$ of culture.

$\ddagger$ The numbers in parentheses indicate the specific activity [IU (mg protein $)^{-1}$ ].

Table 2. Effect of sorbose on growth parameters of $T$. reesei $C-5$ in submerged culture on $1 \%$ glucose

Each specific growth rate $(=\ln 2 /$ doubling time $)$ and yield is the mean of three experiments. The values for replicate assays in all cases differed by less than $15 \%$ from the mean.

\begin{tabular}{|c|c|c|c|c|}
\hline \multirow{2}{*}{$\begin{array}{l}\text { Growth } \\
\text { parameter }\end{array}$} & \multicolumn{3}{|c|}{ Sorbose concn in medium } & \multirow{2}{*}{$\begin{array}{l}\text { Value on } 1 \% \text { sorbose } \\
\text { expressed as percentage } \\
\text { of } 0 \% \text { value }\end{array}$} \\
\hline & $0 \%$ & $1 \%$ & $5 \%$ & \\
\hline $\begin{array}{l}\text { Specific growth rate } \\
\left(\mu, \mathrm{h}^{-1}\right) \\
\text { yield, }(Y, \mathrm{~g} \text { cell }\end{array}$ & $0 \cdot 215$ & $0 \cdot 165$ & 0.078 & $76 \cdot 7 \%$ \\
\hline dry wt/g sugar) & 0.52 & $0 \cdot 28$ & $0 \cdot 20$ & $53.8 \%$ \\
\hline
\end{tabular}




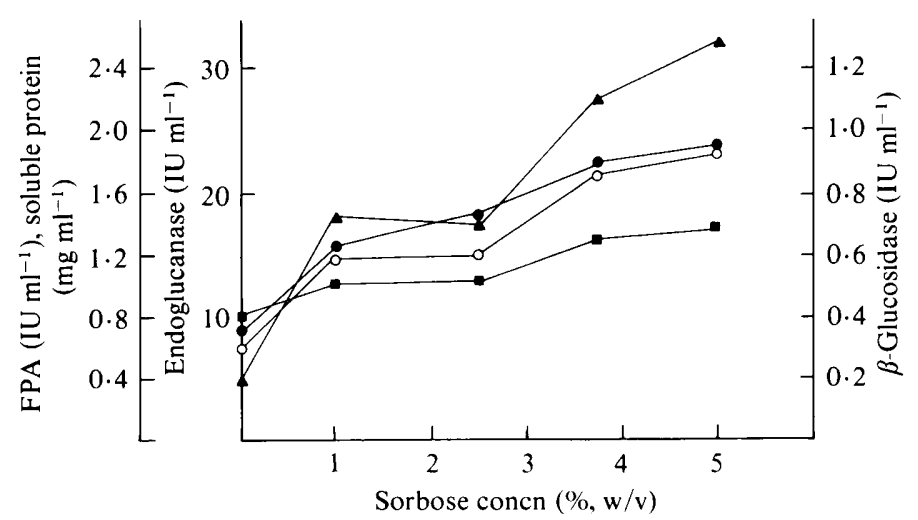

Fig. 1. Effect of increasing concentrations of sorbose on cellulase enzymes in $T$. reesei $\mathrm{C}-5$ grown on $1 \%$ glucose. The extracellular supernatant harvested on day 6 was assayed for various enzymes as described in the text. The data points represent means of three experiments; values for replicate assays differed by less than $10 \%$ from the mean. Sorbose was added at the beginning of the experiment. Soluble protein; $O$, FPA; $\boldsymbol{\Delta}$, endoglucanase; $\boldsymbol{\square}, \boldsymbol{\beta}$-glucosidase.

Table 3. Specific consumption rate of sugar(s) by $T$. reesei $C-5$ grown on glucose and/or sorbose

All assays were done in duplicate on three independent cultures. The values for replicate assays in all cases differed by less than $7 \%$ from the mean.

\section{Culture medium containing}

Glucose $(1 \%)$
Sorbose $(1 \%)$
Sorbose $(5 \%)$
Glucose $(1 \%)+$ sorbose $(1 \%)$
Glucose $(1 \%)+$ sorbose $(5 \%)$

\begin{tabular}{|c|c|c|}
\hline Glucose & Sorbose & $\begin{array}{c}\text { Total sugar } \\
\text { (glucose }+ \text { sorbose) }\end{array}$ \\
\hline $0 \cdot 2$ & - & 0.2 \\
\hline - & 0.03 & 0.03 \\
\hline - & $0 \cdot 10$ & $0 \cdot 1$ \\
\hline 0.17 & 0.025 & $0 \cdot 195$ \\
\hline 0.057 & 0.06 & 0.117 \\
\hline
\end{tabular}

specific consumption rate of sorbose was a function of the sorbose concentration in the medium; it decreased in the presence of $1 \%$ glucose.

Effect of sorbose concentration on cellulase synthesis. The presence of sorbose in the culture medium (either alone or in combination with glucose) led to increased enzyme synthesis (Table 1). The effect of increasing sorbose concentration $(1-5 \%)$ in $1 \%$ glucose medium was investigated to determine if any further stimulation of enzymes could be achieved (Fig. 1). While all three enzyme activities measured were enhanced, the effect on endoglucanase was the most pronounced (sevenfold increase over the control $1 \%$ glucose culture).

Effect of sorbose on distribution of enzymes in subcellular fractions. Table 4 shows the distribution of FPA, endoglucanase, amylase, $\beta$-glucosidase and acid phosphatase in subcellular fractions of $T$. reesei C-5 grown in medium with glucose and/or sorbose. While sorbose increased the overall FPA and endoglucanase activity, the distribution of the enzymes in subcellular fractions remained unchanged when compared to glucose-grown cultures. For amylase, there was no increase in enzyme activity on addition of sorbose and the distribution also remained unchanged. In the case of $\beta$-glucosidase, sorbose markedly increased the proportion of extracellular enzyme, and both intracellular and cell-wall-associated activities were decreased when compared to glucose-grown cultures. The total $\beta$-glucosidase activity remained the same. For acid phosphatase, the total activity was increased by $38 \%$ in the mixed sugar culture compared with the glucose culture, and the extracellular fraction of the enzyme was increased by 
Table 4. Effect of $\mathrm{L}$-sorbose on distribution of enzymes in subcellular fractions of $T$. reesei $C-5$

Cultures were harvested at the end of day 4 , and subcellular fractions were prepared and assayed for activities of various enzymes. All activities represent a mean of three separate experiments. The values in replicate assays in all cases differed by less than $10 \%$ from the mean value.

\begin{tabular}{|c|c|c|c|c|c|c|c|c|}
\hline \multirow[b]{2}{*}{ Enzyme } & \multirow[b]{2}{*}{$\begin{array}{l}\text { Growth } \\
\text { medium* }\end{array}$} & \multicolumn{2}{|c|}{ Extracellular activity } & \multicolumn{2}{|c|}{ Intracellular activity } & \multicolumn{2}{|c|}{ Cell wall fraction } & \multirow{2}{*}{$\begin{array}{c}\text { Total } \\
\text { activity } \\
\text { IU ml-1 }\end{array}$} \\
\hline & & $\mathrm{IU} \mathrm{ml} \mathrm{ml}^{-1}$ & $\begin{array}{c}\% \text { of total } \\
\text { activity }\end{array}$ & $\mathrm{IU} \mathrm{ml^{-1 }}$ & $\begin{array}{c}\% \text { of total } \\
\text { activity }\end{array}$ & $\mathrm{IU} \mathrm{ml} \mathrm{m}^{-1} \dagger$ & $\begin{array}{l}\% \text { of total } \\
\text { activity }\end{array}$ & \\
\hline FPA & $\begin{array}{c}\mathrm{G} \\
\mathrm{S} \\
\mathrm{G}+\mathrm{S}\end{array}$ & $\begin{array}{l}0.38 \\
0.63 \\
0.85\end{array}$ & $\begin{array}{l}71 \cdot 6 \\
73 \cdot 0 \\
75 \cdot 2\end{array}$ & $\begin{array}{l}0 \cdot 15 \\
0 \cdot 23 \\
0 \cdot 28\end{array}$ & $\begin{array}{l}28 \cdot 3 \\
27 \cdot 0 \\
24 \cdot 8\end{array}$ & $\begin{array}{l}<0.005 \\
<0.005 \\
<0.005\end{array}$ & & $\begin{array}{l}0.53 \\
0.86 \\
1.13\end{array}$ \\
\hline Endoglucanase & $\begin{array}{c}G \\
S \\
G+S\end{array}$ & $\begin{array}{l}3 \cdot 5 \\
7 \cdot 06 \\
12 \cdot 5\end{array}$ & $\begin{array}{l}84 \cdot 4 \\
88 \cdot 3 \\
90 \cdot 0\end{array}$ & $\begin{array}{l}0 \cdot 7 \\
0.94 \\
1.4\end{array}$ & $\begin{array}{l}15 \cdot 6 \\
11 \cdot 7 \\
10 \cdot 0\end{array}$ & $\begin{array}{l}<0.01 \\
<0.01 \\
<0.01\end{array}$ & & $\begin{array}{r}4 \cdot 2 \\
8 \cdot 0 \\
13 \cdot 9\end{array}$ \\
\hline Amylase & $\begin{array}{c}\mathrm{G} \\
\mathrm{S} \\
\mathrm{G}+\mathrm{S}\end{array}$ & $\begin{array}{l}7 \cdot 0 \\
5 \cdot 0 \\
6 \cdot 23\end{array}$ & $\begin{array}{l}92.8 \\
93.6 \\
93.0\end{array}$ & $\begin{array}{l}0.54 \\
0 \cdot 34 \\
0 \cdot 47\end{array}$ & $\begin{array}{l}7 \cdot 2 \\
6 \cdot 4 \\
7 \cdot 0\end{array}$ & $\begin{array}{l}<0.05 \\
<0.05 \\
<0.05\end{array}$ & & $\begin{array}{l}7 \cdot 54 \\
5 \cdot 34 \\
6 \cdot 7\end{array}$ \\
\hline$\beta$-Glucosidase & $\begin{array}{c}\mathrm{G} \\
\mathrm{S} \\
\mathrm{G}+\mathrm{S}\end{array}$ & $\begin{array}{l}0.28 \\
0.48 \\
0.42\end{array}$ & $\begin{array}{l}51 \cdot 0 \\
81 \cdot 3 \\
79 \cdot 2\end{array}$ & $\begin{array}{l}0.18 \\
0.07 \\
0.05\end{array}$ & $\begin{array}{r}32 \cdot 7 \\
11 \cdot 8 \\
9 \cdot 4\end{array}$ & $\begin{array}{l}0.09 \\
0.04 \\
0.06\end{array}$ & $\begin{array}{r}16 \cdot 3 \\
6 \cdot 9 \\
11 \cdot 4\end{array}$ & $\begin{array}{l}0.55 \\
0.59 \\
0.53\end{array}$ \\
\hline Acid phosphatase & $\begin{array}{c}\mathrm{G} \\
\mathrm{S} \\
\mathrm{G}+\mathrm{S}\end{array}$ & $\begin{array}{l}0.33 \\
0.34 \\
0.65\end{array}$ & $\begin{array}{l}56.9 \\
82.9 \\
81 \cdot 2\end{array}$ & $\begin{array}{l}0.25 \\
0.068 \\
0 \cdot 15\end{array}$ & $\begin{array}{l}43 \cdot 1 \\
16 \cdot 5 \\
18 \cdot 7\end{array}$ & $\begin{array}{l}<0.01 \\
<0.01 \\
<0.01\end{array}$ & & $\begin{array}{l}0.58 \\
0.41 \\
0.80\end{array}$ \\
\hline
\end{tabular}

* G, $2 \%$ glucose; $\mathrm{S}, 2 \%$ sorbose; $\mathrm{G}+\mathrm{S}, 1 \%$ glucose plus $1 \%$ sorbose.

$\dagger$ The values of $0.005 \mathrm{IU} \mathrm{ml}^{-1}$ (FPA), $0.01 \mathrm{IU} \mathrm{ml}^{-1}$ (endoglucanase, acid phosphatase) and 0.05 units $\mathrm{ml}^{-1}$ (amylase) correspond to the limit of detection for these assays.

$\ddagger$ Amylase values are not in IU ml-1. For details see Methods.

a similar proportion. Less enzyme (about $19 \%$ ) remained associated intracellularly compared to $43 \%$ in the glucose-grown culture.

\section{DISCUSSION}

The effect of L-sorbose on growth parameters (specific growth rate and yield) and enzyme production in $T$. reesei $\mathrm{C}-5$ has been investigated. The parent $T$. reesei QM9414 does not metabolize sorbose (Bisaria et al., 1986). Both glucose and sorbose were taken up simultaneously by strain C -5 although the specific consumption rates were affected by the presence of the other sugar.

Addition of sorbose lowered the specific growth rate and yield of strain C-5 (Table 2). These results were different from those reported for $N$. crassa by Crocken \& Tatum (1968) and Trinci \& Collinge (1973), where addition of sorbose to glucose cultures caused no change in specific growth rate and yield.

Both FPA and endoglucanase activity were enhanced on addition of $1 \%$ sorbose to $1 \%$ glucose cultures. Such enhanced activities could not be correlated with increase in biomass content, as this remained comparable to that in glucose cultures. It seems likely that a decreased level of intracellular glucose in sorbose plus glucose cultures is responsible for this effect: both these enzymes are known to be regulated by glucose (Mandels \& Weber, 1969). This explanation is supported by the observation that amylase, an extracellular constitutive enzyme in $T$. reesei (Nisizawa et al., 1972) and known not to be affected by glucose, was synthesized to the same extent in glucose and in mixed sugar cultures (Table 4).

The enzyme $\beta$-glucosidase is reported to be predominantly associated with the cell wall in $T$. reesei QM9414 (Nanda et al., 1982). It is also constitutive and not affected by the presence of various sugars in the medium (Mishra \& Gopalkrishnan, 1984); hence its activity cannot be expected to be increased by sorbose. However, addition of sorbose is known to cause dissociation of cell-wall-associated enzymes. Thus in $T$. reesei $\mathrm{C}$-5, although total $\beta$-glucosidase 
activity remained the same for sorbose cultures as compared with glucose cultures, the percentage in extracellular fractions increased. Such increased release of enzymes by addition of sorbose has been attributed to increased branching and formation of an increased number of hyphal tips in this fungus (Bisaria et al., 1986). The same pattern was also noticed for acid phosphatase, where more enzyme was released to the external medium in the presence of sorbose (Table 4).

Thus by carefully regulating the supply of glucose to $T$. reesei in continuous cultures it should be possible to increase the overall yield of cellulase. By supplementing the culture with paramorphogenic agents such as sorbose and certain colloids (Duff et al., 1985) it should be possible to produce a mixture of enzymes, rich in all components of cellulase, ideal for efficient biomass conversion.

\section{REFERENCES}

Berghem, L. E. R. \& Pettersson, L. G. (1974). Mechanism of enzymic cellulose degradation: isolation and properties of a $\beta$-glucosidase from Trichoderma viride. European Journal of Biochemistry 46, 295-305.

Bergmeyer, H. U. \& Brent, E. B. (1974). Glucose: determination with glucose oxidase and peroxidase. In Methods of Enzymatic Analysis, 2nd edn, vol. III, pp. 1205-1212. Edited by H. U. Bergmeyer. New York: Verlag Chemie/Academic Press.

BiSARIA, V. S. \& Ghose, T. K. (1981). Biodegradation of cellulosic materials; substrates, microorganisms, enzymes and products, Enzyme and Microbial Technology 3, 90-104.

Bisaria, V. S., Nanda, M. \& Ghose, T. K. (1986). Effect of $L(-)$ sorbose on release of $\beta$-glucosidase by Trichoderma reesei QM9414. Journal of General Microbiology 132, 973-978.

Crocken, B. \& TAtum, E. L. (1968). The effect of sorbose on metabolism and morphology of Neurospora. Biochimica et biophysica acta 156, 1-8.

DisCHE, Z. \& DEVI, A. (1960). A new colorimetric method for determination of ketohexoses in presence of aldoses, ketoheptoses and ketopentoses. Biochimica et biophysica acta 39, 140-144.

DuFF, S. J. B., COOPER, D. G. \& Fuller, O. M. (1985). Effect of colloidal materials on cellulase production by Trichoderma reesei Rut $\mathrm{C} 30$. Applied and Environmental Microbiology 49, 934-938.

GilberT, I. G. \& TsAo, G. T. (1983). Interaction between solid substrate and cellulase enzymes in cellulosic hydrolysis. In Annual Reports of Fermentation Processes, vol. 6, pp. 323-358. Edited by G. T. Tsao. New York: Academic Press.

MANDELS, M. \& WEBER, J. (1969). The production of cellulases. Advances in Chemistry Series 95, 391414.
Mandels, M., Andreotti, R. A. \& Roche, C. D. (1976). Measurement of saccharifying cellulase. Biotechnology and Bioengineering Symposium 6, 2133.

Mishra, S. \& Gopalkrishnan, K. S. (1984). New method for isolation of cellulase constitutive mutant of Trichoderma reesei and partial characterization of one. Journal of Fermentation Technology 62, 495-501.

Mishra, S., Gopalkrishnan, K. S. \& Ghose, T. K. (1982). A constitutively cellulase producing mutant of Trichoderma reesei. Biotechnology and Bioengineering 24, 251-254.

Nanda, M., Bisaria, V. S. \& Ghose, T. K. (1982). Localization and release mechanism of cellulases in Trichoderma reesei QM9414. Biotechnology Letters 4 , 633-637.

Nisizawa, T., Suzuki, H. \& Nisizawa, K. (1972). Catabolite repression of cellulase formation in Trichoderma viride. Journal of Biochemistry 71, 9991007.

Stavy, R., Stavy, L. \& Galun, E. (1970). Protein synthesis in aged and young zones of Trichoderma colonies. Biochimica et biophysica acta 217, 468-474.

Sumner, J. B. \& Somers, G. F. (1949). Dinitrosalicylic method for glucose. In Laboratory Experiments in Biological Chemistry, 2nd edn, pp. 38-39. New York: Academic Press.

TAtUM, E. L., Barret, R. W. \& CutTer, V. M. (1949). Chemical induction of colonial paramorphs in Neurospora and Syncephalastrum. Science 109, 509511.

TRINCI, A. P. J. \& Collinge, A. (1973). Influence of Lsorbose on the growth and morphology of Neurospora crassa. Journal of General Microbiology 78, 179-192.

VoGEL, H. J. (1956). A convenient growth medium for Neurospora (medium N). Microbial Genetics Bulletin $13,42-45$ 